\title{
Cell wall synthesis in cotton roots after infection with Fusarium oxysporum
}

\section{The deposition of callose, arabinogalactans, xyloglucans, and pectic components into walls, wall appositions, cell plates and plasmodesmata}

\author{
E. Rodriguez-Gálvez, K. Mendgen \\ Lehrstuhl für Phytopathologie, Fakultät für Biologie der Universität Konstanz, D-78434 Konstanz, Germany
}

Received: 13 April 1995/Accepted: 13 June 1995

\begin{abstract}
Fusarium oxysporum f. sp. vasinfectum penetration hyphae infect living cells in the meristematic zone of cotton (Gossypium barbadense L.) roots. We characterized wall modifications induced by the fungus during infection of the protodermis using antibodies against callose, arabinogalactan-proteins, xyloglucan, pectin, polygalacturonic acid and rhamnogalacturonan $I$ in high-pressure frozen, freeze-substituted root tissue. Using quantitative immunogold labelling we compared the cell walls before and after hyphal contact, cell plates with plasmodesmata during cytokinesis, and wall appositions induced by fungal contact. In the already-existing wall, fungal contact induced only minor modifications such as an increase of xyloglucan epitopes. Wall appositions mostly exhibited epitopes similar to the cell plate except that wall appositions had a much higher callose content. This study shows that wall appositions induced by Fusarium oxysporum hyphae are the result of normal cell wall synthesis and the addition of large amounts of callose. The appositions do not stop fungal growth.
\end{abstract}

Key words: Arabinogalactan - Callose - Fusarium - Gossypium - High pressure freezing (freeze substitution) Papilla

\section{Introduction}

Formation of wall appositions, called papillae, constitutes a typical response of plant cells after wounding (Russo and Bushnell 1989; Homblé and Foissner 1993) or fungal infection (Aist and Bushnell 1991; Smart 1991). The structure of wall appositions can vary considerably. Exactly localized papilla-like appositions are produced at the site of fungal penetration, whereas extended appositions may

Abbreviations: $\quad A G=$ arabinogalactan; $\quad A G P=$ arabinogalactanglycoprotein; HRGP = hydroxyproline-rich glycoprotein; $\mathrm{RGI}=$ rhamnogalacturonan $\mathrm{I} ; \mathrm{XG}=$ xyloglucan

Correspondence to: K. Mendgen; FAX: 49 (7531) 883035 develop after elicitation in cultured cells (Hohl and Suter 1976; Ride and Pearce 1979; Kauss 1995). Fungal structures such as hyphae or haustoria may become completely encased (Heath 1972). In barley epidermal cells infected by Erysiphe graminis the wall apposition is produced soon after fungal contact with the plant cuticle (Kunoh 1982). Such appositions are produced by a cytoplasmic aggregate that accumulates within a few minutes at the site of fungal penetration (Bushnell 1984; Aist and Bushnell 1991; Xu and Mendgen 1994; Freytag et al. 1994).

In a first step of the wound response, the host plant seems to strengthen the wall by oxidative crosslinking of pre-existing hydroxyproline-rich structural proteins (Brisson et al. 1994) or by infiltration with silicon and lipids (Sargent and Gay 1977; Kunoh 1982). Simultaneously, a $(1 \rightarrow 3)-\beta$-D-glucan synthase located in the plasmalemma starts with the production and deposition of callose (Hächler and Hohl 1984; Kauss 1995). Hydroxyproline-rich glycoproteins (HRGPs) are added to the apposition (Esquerré-Tugayé et al. 1979). Other constituents of wall appositions can be lignin (Sherwood and Vance 1982), pectin (Smart 1991) and antimicrobial wall proteins (Bohlmann and Apel 1991). A comparison of appositional wall material with the molecules typically found in the cell plate during cell wall synthesis is missing. In the latter cases the input of the individual wall components is highly regulated, varies within different plant families and also depends on the developmental stage of the tissue (Carpita and Gibeaut 1993; Gibeaut and Carpita 1994, Roberts 1994). In the protodermis of cotton root tips, the development of new walls and the synthesis of wall appositions after infection with Fusarium oxysporum occur simultaneously without macroscopic symptoms at the root tips (Rodríguez-Gálvez and Mendgen 1995). In this host-parasite system, it is therefore possible to follow the deposition of typical wall constituents during the synthesis of the cell wall and the wall apposition induced by fungal contact in cells of a similar developmental stage. By using specific antibodies against the different components of plant walls (Knox 1992; Pennell 1992; Puhlmann et al. 1994) we observed that, in addition to callose deposition, normal cell wall synthesis takes place during development of wall 
appositions. Only minor modifications occur in fully developed walls after contact with the fungus.

\section{Material and methods}

Plant and fungus. Cotton (Gossypium barbadense L. cv. Pima) seeds (Departamento de Sanidad Vegetal, Universidad Nacional de Piura, Peru) were surface-sterilized for 5 min with $6.5 \%$ (v/v) sodium hypochlorite, rinsed in sterile water and allowed to germinate on filter paper at $28^{\circ} \mathrm{C}$ for $2 \mathrm{~d}$ in the dark. Fusarium oxysporum Schlecht f. sp. vasinfectum (ATK.) Snyd. and Hans. was cultured on potato-dextrose-agar as described previously (Rodriguez-Gálvez and Mendgen 1995).

Inoculation. Microconidia were obtained by filtration through cotton wool and centrifugation for $10 \mathrm{~min}$ at $150 \cdot \mathrm{g}$. Microconidia were resuspended in distilled water and spread on agar. The number of conidia was determined and small agar pieces $(1 \mathrm{~mm}$ diameter $)$ were placed on the root tip in the meristematic zone with the spores facing the root surface.

Tissue processing and electron microscopy. Twenty-four hours after inoculation roots were infiltrated with $8 \%(\mathrm{v} / \mathrm{v})$ methanol and immediately placed into 2-mm-diameter, $0.2-\mathrm{mm}$-deep aluminium cups. Within $5 \mathrm{~min}$ after infiltration, samples were frozen in a Balzers HPM 10 (Balzers Union Liechtenstein) high-pressure-freezing instrument (Mendgen et al. 1991). Samples were freeze-substituted with $2 \%(\mathrm{w} / \mathrm{v})$ osmium tetroxide in acetone in three steps: $24 \mathrm{~h}$ at $-90^{\circ} \mathrm{C}, 12 \mathrm{~h}$ at $-60^{\circ} \mathrm{C}$ and $9 \mathrm{~h}$ at $-30^{\circ} \mathrm{C}$. After substitution, the temperature was raised to $0^{\circ} \mathrm{C}$, the samples were rinsed three times for $15 \mathrm{~min}$ with acetone and infiltrated with epon-araldite epoxide resin. After polymerization at $60^{\circ} \mathrm{C}$, sections were cut with an Ultracut E microtome (Reichert-Jung, Wien, Austria) and spread on Formvar-coated slot grids. After labelling and staining, sections were washed with distilled water and evaluated with an EM $10 \mathrm{CR}$ electron microscope (Zeiss, Oberkochen, Germany) operated at $60 \mathrm{kV}$.

Antibodies. Production, characterization and specificity of the polyclonal antibody against $(1 \rightarrow 3)$ - $\beta$-D-glucan (\# CH-11-512, ICI, Wilmington, N.C., USA) has been described by Northcote et al. (1989). The monoclonal antibodies CCRC-M1, CCRC-M2 and CCRC-M8 were described by Puhlmann et al. (1994) and obtained from Dr. Michael Hahn. The CCRC-M1 recognizes an epitope containing $(1 \rightarrow 2)$-linked $\alpha$-fucosyl residues found principally on xyloglucan (XG) and to a lesser extent on rhamnogalacturonan I (RGI; Puhlmann et al. 1994). The antibody CCRC-M2 binds to RGI without binding to other pectic polysaccharides. The antibody CCRC-M8 recognizes an arabinosylated $(1 \rightarrow 6)$-linked $\beta$-galactan epitope, but also has affinities to arabinogalactan-proteins (AGPs; Puhlmann et âl. 1994; Steffan et al. 1995). Unlike other antibodies against AGPs (Knox et al. 1989), CCRC-M8 does not bind to gum arabic (Puhlmann et al. 1994). The monoclonal antibodies JIM 5 and JIM 7 were obtained from Dr. Paul Knox; JIM 5 recognizes polygalacturonic acid and JIM 7 recognizes methyl-esterified epitopes of pectin (Knox et al. 1990).

Immunolabelling. Grids were placed on water for $1 \mathrm{~min}$ in a highhumidity chamber. Then they were treated with blocking buffer for $30 \mathrm{~min}$ at room temperature. For the callose antibody, the blocking buffer (pH 7) consisted of $10 \mathrm{mM} \mathrm{Na}$-phosphate, $500 \mathrm{mM} \mathrm{NaCl}$, $0.1 \%(\mathrm{v} / \mathrm{v})$ Tween 20 and $5 \%(\mathrm{w} / \mathrm{v})$ defatted milk powder $(1 \%$ fat, $36 \%$ protein). For the monoclonal antibodies, the blocking buffer (pH 7.2) consisted of $10 \mathrm{mM}$ Na-phosphate, $50 \mathrm{mM} \mathrm{NaCl}$ and $1 \%$ bovine serum albumin (BSA; Serva, Heidelberg, Germany). For incubation, the polyclonal antibody was diluted 1:400 and the monoclonal antibody was diluted $1: 10$ in the respective buffer, but without milk powder or BSA. Incubation time was $1 \mathrm{~h}$ at room temperature for the polyclonal antibody or overnight at $4{ }^{\circ} \mathrm{C}$ for the monoclonal antibodies. After three washes for $1 \mathrm{~min}$, each grid was incubated for $1 \mathrm{~h}$ at room temperature with the secondary antibodies. The polyclonal antibody against callose was incubated with goat-anti-rabbit immunoglobulin $\left(I_{g}\right) G$ coupled to $10-\mathrm{nm}$ colloidal gold (Bio Cell, Cardiff, UK). The antibodies CCRC-M1, CCRC-M2, CCRC-M8 were detected with goat-anti-mouse IgG + IgM coupled to $15-\mathrm{nm}$ gold, and JIM 5 and JIM 7 were detected with goat-antirat IgG coupled to 15-nm gold (Bio Cell). Secondary antibodies were diluted 1:10 with the same buffer as above. After washing with distilled water, grids were treated with $2 \%$ glutaraldehyde for $30 \mathrm{~s}$ and again washed with distilled water. The specificity of antibody labelling was determined by replacing the primary antibody with buffer. Sections were stained for $8 \mathrm{~min}$ with a mixture $(1: 120)$ of potassium permanganate $\left(0.8 \% \mathrm{KMnO}_{4}\right.$ in $0.1 \mathrm{M} \mathrm{Na}$-phosphate buffer, $\mathrm{pH}$ 5.2) and uranyl acetate ( $3 \%$ in water; Hayat 1975$)$.

Quantification of immunolabelling. The number of gold particles $\cdot \mu^{-2}$ was counted over wall appositions, cell walls in contact with fungal hyphae and over cell walls without fungal hyphae in the vicinity. For some antibodies, gold particles were also counted over the middle lamella, either in contact with hyphae or at least one cell away from any fungal hypha. Since the area of the cell plate was difficult to determine, we counted the gold particles within a zone $125 \mathrm{~nm}$ wide along the middle of the cell plate. Density of gold particles over plasmodesmata was counted in a zone $200 \mathrm{~nm}$ wide along the plasmodesma. Density over the plasmalemma was determined over a zone $60 \mathrm{~nm}$ wide, on each side of the membrane. For background determinations, plant nuclei of the protodermis, chosen randomly, were used. For each variant, micrographs $\times 40000$ were evaluated. The areas of walls or organelles were measured with a Tamaya digital planimeter (Tamaya Technics Inc., Sokutama, Japan).

Stastistical analysis. For the analysis of the results the statistical program Statistica/Mac (StatSoft, Tuesa, Okea., USA) was used. The non-parametric test-system of Kruskal Wallis ANOVA, was used for the variance analysis and for the comparison of the treatments.

\section{Results}

Fusarium oxysporum forms a compact mycelium over the root surface. From this mycelium, penetration hyphae branch off and infect the rhizodermis by penetrating intraand intercellularly. Along the hyphae, plant cells produce prominent wall appositions (Rodriguez-Galvez and Mendgen 1995). This study describes modifications in the wall and the components of the wall appositions after fungal infection of the protodermis, close to the apical meristem of the cotton root.

Callose. The antibodies raised against $(1 \rightarrow 3)-\beta-\mathrm{D}-$ glucans heavily labelled the cell wall appositions, which are produced along the plant wall after contact with fungal hyphae (Fig. 1) and later, during penetration of the fungus into the host cell, around the penetration hypha (Fig. 2). In each case label density over the wall apposition was identical. From the appositions, slender-tipped and densely labelled extrusions surrounded by the plasmalemma reached into the cytoplasm (Figs. 1,2). The dark and light areas of the wall appositions exhibited a somewhat uneven distribution of label with a preference for the lighter areas. However, we were not able to prove this observation quantitatively because it was difficult to discriminate the areas exactly. In non-infected protodermal cells, only areas along the plasmodesmata (Fig. 4) and spots in the cell plate (Fig. 3) were labelled. The density of label over wall appositions and plasmodesmata was 


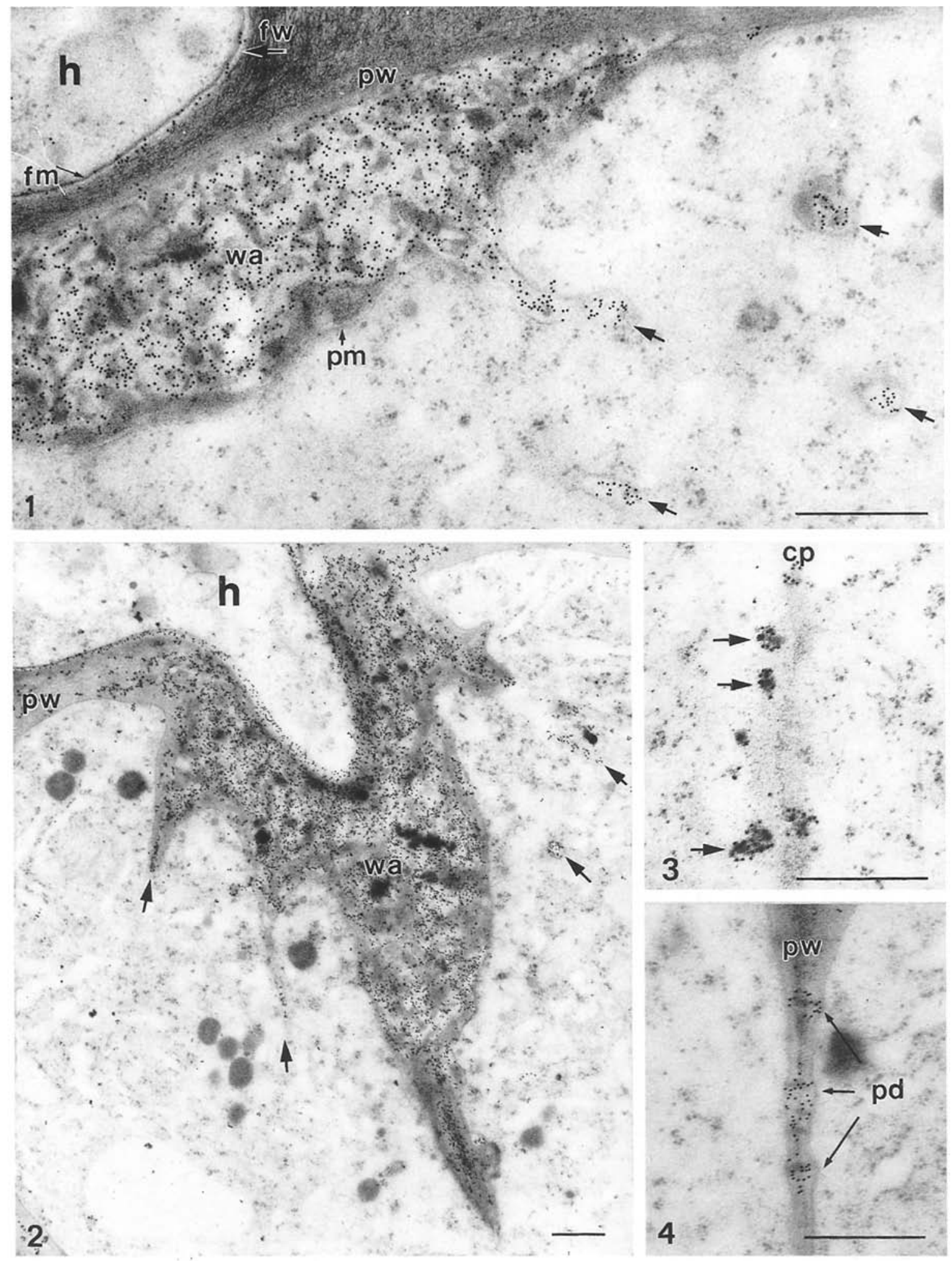

Figs. 1-4. Label distribution with the polyclonal antiserum against (1,3)- $\beta$-D-glucan. Fig. 1. The wall apposition, its extensions (arrows) and the fungal wall are labelled. $\times 42500$. Fig. 2. Label over wall apposition, around a penetration hypha, and extensions of the wall apposition. $\times 17000$. Fig. 3. Label over the cell plate. $\times 42500$. Fig. 4. Label over plasmodesmata. $\times 40800$. Bars $=0.5 \mu \mathrm{m} . c p$, cell plate; $h$, hypha, $f m$, fungal plasma membrane; $f w$; fungal cell wall; $p d$; plasmodesmata; $p m$, plant plasma membrane; $p w$, plant cell wall; wa, wall apposition 

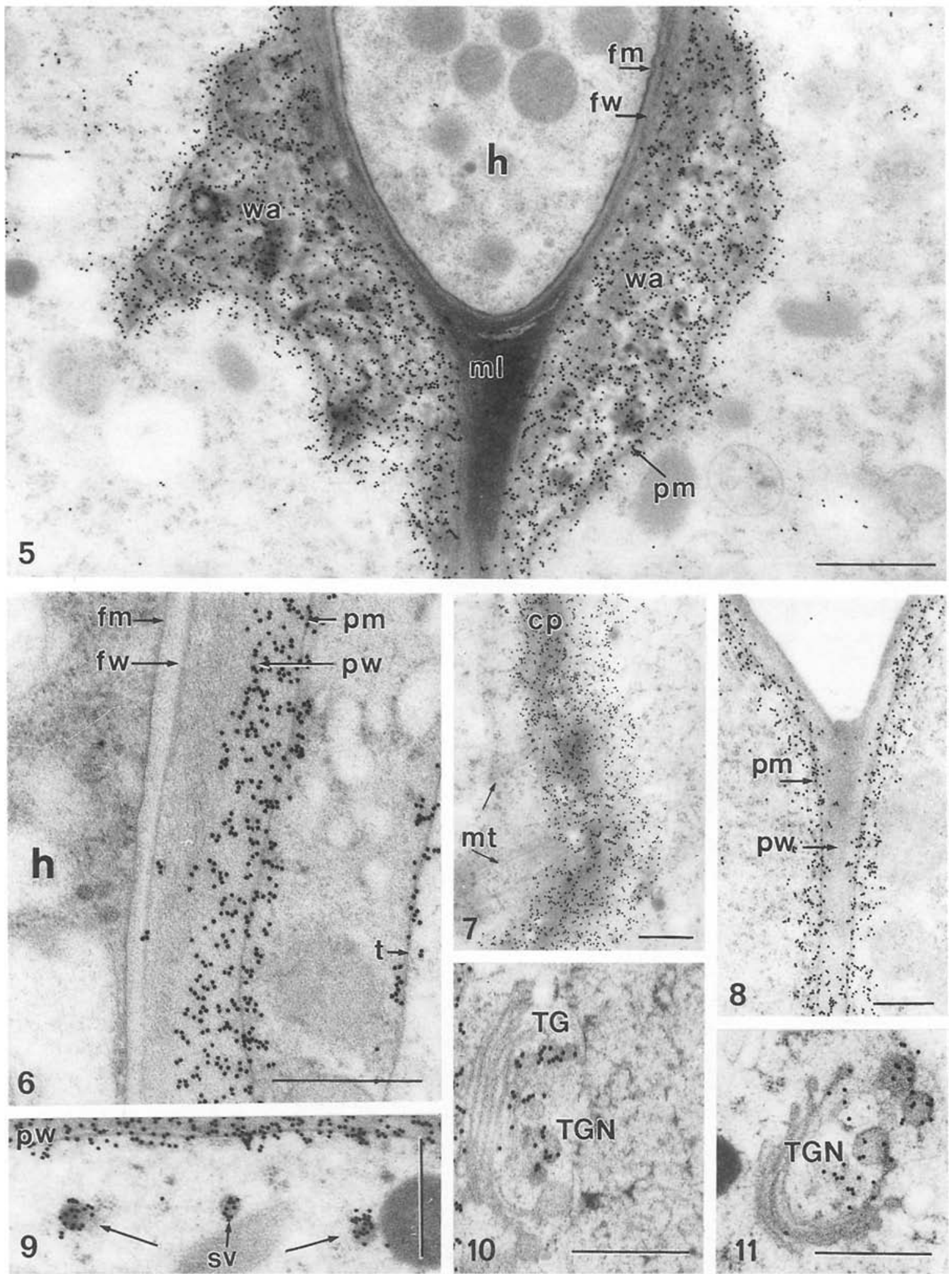

Figs. 5-11. Label distribution with the CCRC-M8 monodonal antibody against arabinosylated $(1 \rightarrow 6)$ - $\beta$-galactan epitopes on AG/AGP. Fig. 5. The wall apposition $(w a)$ is labelled. $\times 38250$. Fig. 6. Label over and along the plant plasma membrane and tonoplast. $\times 47600$. Fig. 7 . Label over the cell plate. $\times 17000$. Fig. 8. Label over the inner surface of plant cell walls. $\times 19125$. Fig. 9. Label over secretory vesicles. $\times 37$ 190. Fig. 10. Label over trans-Golgi cisternae and trans-Golgi network. $\times 37$ 190. Fig. 11 . Label over the trans-Golgi network. $\times 37190$. Bars $=0.5 \mu \mathrm{m}$. $c p$, cell plate; $h$, hypha; $f m$, fungal plasma membrane; $f w$, fungal cell wall; $m l$, middle lamella; $m t$, microtubules; $p m$, plant plasma membrane; $p w$, plant cell wall; $s v$, secretory vesicles; TG, trans-Golgi cisternae; $t$, tonoplast; TGN, trans-Golgi network; wa, wall apposition 

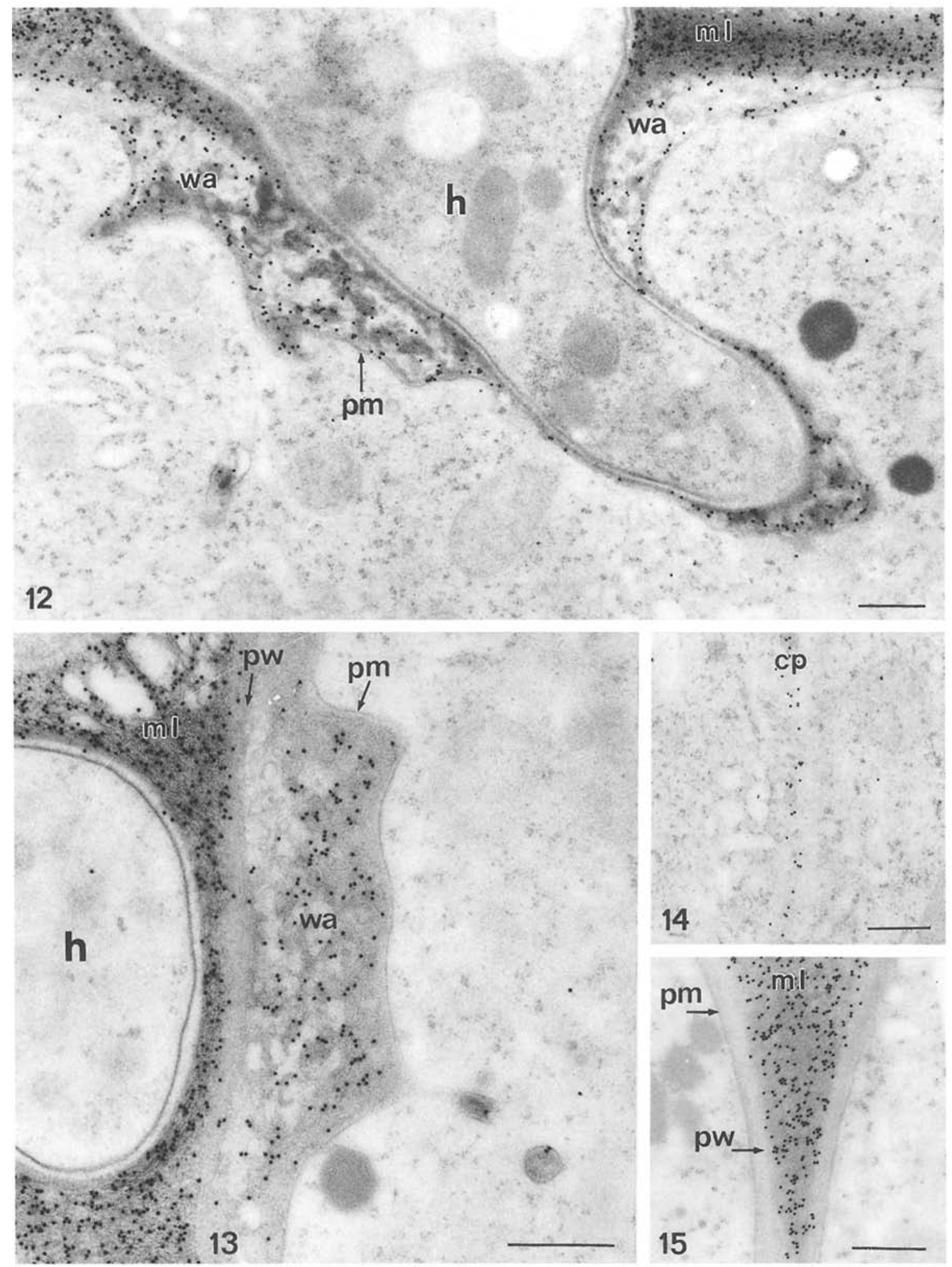

Figs. 12-15. Label distribution with the JIM 5 monoclonal antibody against polygalacturonic acid. Fig. 12. Label over the wall apposition around a penetration hypha. $\times 21250$. Fig. 13. Label over the wall apposition before fungal penetration. $\times 34000$. Fig. 14. Label over the cell plate. $\times 20400$. Fig. 15. Label over the middle lamella. $\times 25500$. Bars $=0.5 \mu \mathrm{m} . c p$, cell plate; $h$, hypha; $m l$, middle lamella; $p m$, plant plasma membrane; $p w$, plant cell wall; $w a$, wall apposition 
similar (see Fig. 32). We found no difference in label density over plasmodesmata in infected or healthy roots (data not shown). In the fungus, the antibodies also had affinity for the wall of the fungus (Fig. 1).

Arabinogalactans/arabinogalactan-proteins (CCRC-M8). The CCRC-M8 anitbody which recognizes arabinogalactans (AGs), evenly labelled the wall appositions produced after fungal contact (Fig. 5) and after fungal penetration (data not shown) with equal intensity. A somewhat higher density was observed over the cell plate (Figs. 7, 33-A). In addition, we observed labelling over the plant wall, excluding the middle lamella and along the plasmalemma (Figs. 6-8). The label over the plasmalemma reached some $90 \mathrm{~nm}$ into the cytosol. Label density on both sides of the plasmalemma counted within a distance of $60 \mathrm{~nm}$ was similar $\left(502 \pm 97\right.$ gold particles $\cdot \mu \mathrm{m}^{-2}$ versus $50.4 \pm 77$ gold particles $\cdot \mu \mathrm{m}^{-2}$ ). We also observed label over the tonoplast (Fig. 6), over secretory vesicles, trans-Golgi cisternae and trans-Golgi network (Figs. 9-11). Label density over walls (Fig. 33-A) and membranes (data not shown) was not affected by fungal infection.

Polygalacturonic acid (JIM 5). The JIM 5 antibody against polygalacturonic acid labelled wall appositions formed along the penetration hypha (Fig. 12) and the wall appositions produced in response to hyphae growing along the middle lamella (Fig. 13). There was no difference in label density in each case, but the dark inclusions within the appositions exhibited higher label density (Figs. 12,13). Label over the cell plate was comparatively reduced $(P<0.05)$. A much higher label density than the
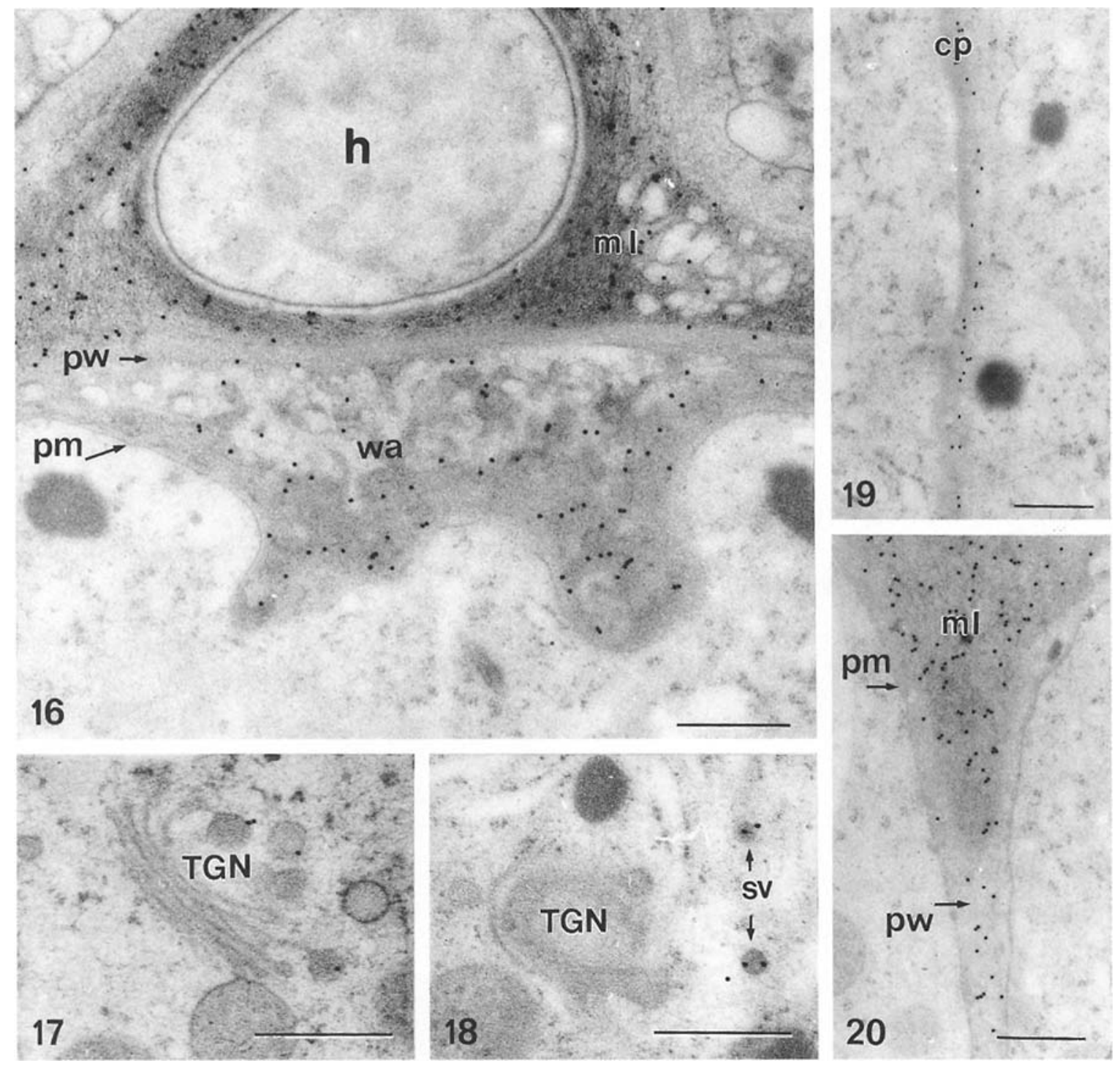

Figs. 16-20. Label distribution with the JIM 7 monoclonal antibody against pectin. Fig. 16. Label over wall apposition and middle lamella. $\times 30600$. Figs. 17-18. Label over trans-Golgi network $(\times 37190)$ and secretory vesicles $(\times 37190)$. Fig. 19 . Label over the cell plate. $\times 21250$. Fig. 20. Label over the middle lamella. $\times 25500$. Bars $=0.5 \mu \mathrm{m} . c p$, cell plate; $h$, hypha; $m l$, middle lamella; $p m$, plant plasma membrane; $p w$, plant cell wall; $s v$, secretory vesicles; $T G N$, trans-Golgi network; wa, wall apposition 
density over wall apposition and cell plate was found over the middle lamellae of infected and non-infected cells (Figs. 14, 15, 33-B). We found no label over the Golgi apparatus or over vesicles close by.

Pectin (JIM 7). Labelling with the JIM 7 antibody against pectin gave very similar results to that with JIM 5. A high density of label was observed over the middle lamella of uninfected and infected cells (Figs. 20,33-C), a lower density over wall appositions and the cell plate (Figs. 16, 19). However, compared to the cell plate, label density over the wall apposition was increased (Fig. 33-C). In contrast to JIM 5, JIM 7 weakly labelled the transGolgi cisternae and secretory vesicles which seemed to originate from the trans-Golgi network (Figs. 17, 18).

Rhamnogalacturonan I (CCRC-M2). The antibody against RGI, CCRC-M2, labelled plant cell walls with and without fungal contact similarly (Figs. 21, 23, 33-D). A lower labelling density was observed over the wall apposition induced by fungal contact (Fig. 21) and the apposition around penetrating hyphae (data not shown). Compared to the cell plate (Fig. 22) the density of label over the wall apposition (Fig. 33-D) was reduced by more than $30 \%(P<0.05)$. Also trans-Golgi cisternae, transGolgi network and secretory vesicles exhibited labelling (Figs. 24-26).

Xyloglucan (CCRC-MI). The CCRC-M1 antibody against fucosylated $X G$ exhibited the highest affinity against plant cell walls in contact with hyphae (Figs. 27, 33-E). Walls of non-infected cells, the cell plate and the wall apposition were labelled with descending density each $(P<0.05$ for each variant; Figs. $28,29,33-\mathrm{E})$. The trans-Golgi network and secretory vesicles also exhibited labelling (Figs. 30, 31).
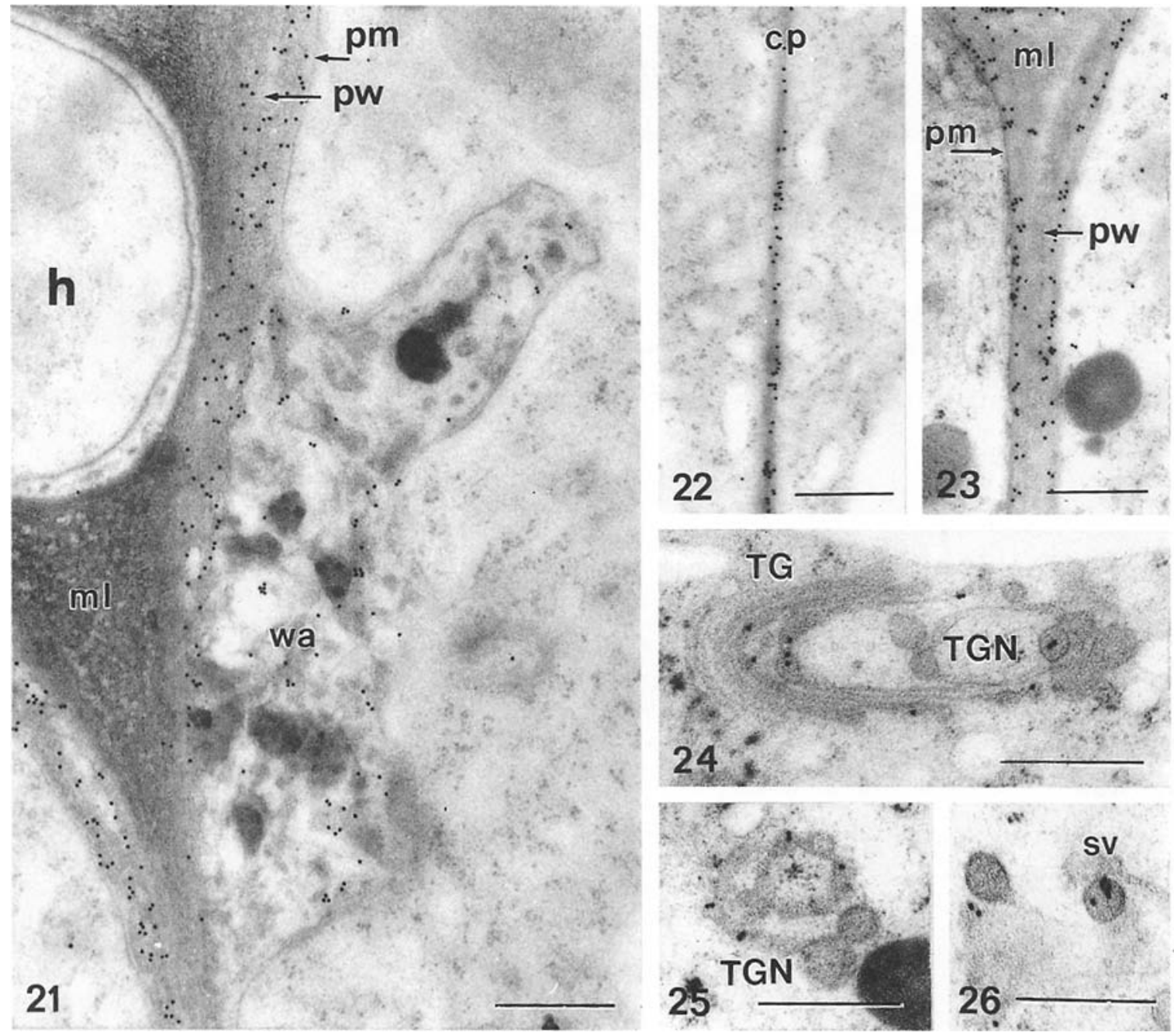

Figs. 21-26. Label distribution with the CCRC-M2 monoclonal antibody against RGI. Fig. 21. Label over wall apposition. $\times 30600$. Fig. 22 . Label over the cell plate. $\times 25500$. Fig. 23. Label over the plant cell wall. $\times 26565$. Fig. 24. Label over the trans-Golgi cisternae and trans-Golgi network. $\times 37$ 190. Fig. 25. Label over the trans-Golgi network. $\times 37190$. Fig. 26. Label over secretory vesicles. $\times 37190$. Bars $=0.5 \mu \mathrm{m} . c p$, cell plate; $h$, hypha; $m l$, middle lamella; $p m$, plant plasma membrane; $p w$, plant cell wall; $s v$, secretory vesicles; $T G$, trans-Golgi cisternae; TGN, trans-Golgi network; wa, wall apposition 

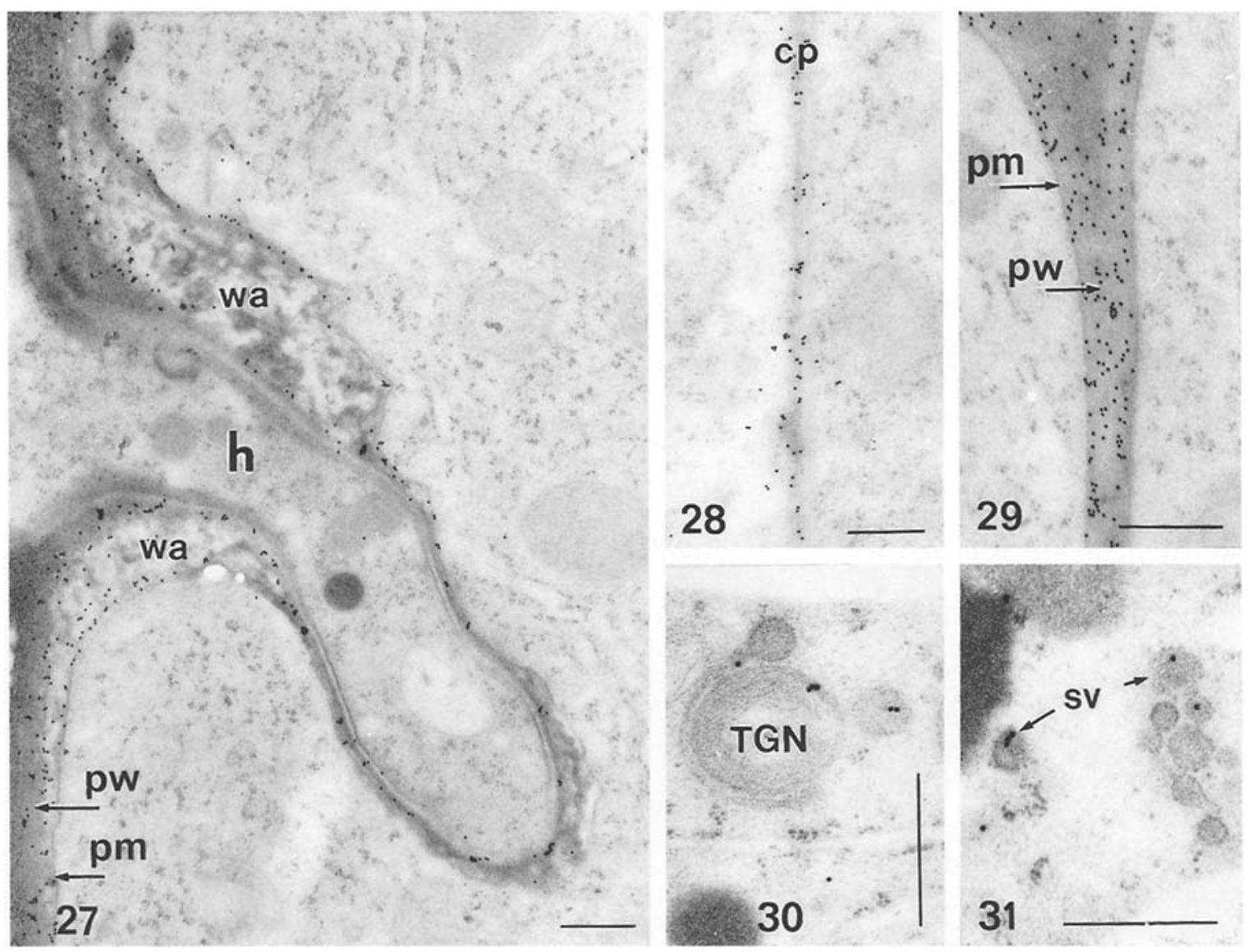

Figs. 27-31. Label distribution with the CCRC-M1 monoclonal antibody against $(1 \rightarrow 2)$-linked $\alpha$-fucosyl residues on XGs. Fig. 27. Label over wall apposition along the penetration hypha. $\times 17000$. Fig. 28. Label over the cell plate. $\times 21250$. Fig. 29. Label over the cell wall. $\times 25$ 500. Fig. 30. Label over trans-Golgi network. $\times 37$ 190. Fig. 31. Label over the secretory vesicles. $\times 43750$. Bars $=0.5 \mu \mathrm{m} . c p$, cell plate; $h$, hypha; $p m$, plant plasma membrane; $p w$, plant cell wall; $s v$, secretory vesicles; $T G$, trans-Golgi cisternae; TGN, trans-Golgi network; wa, wall apposition

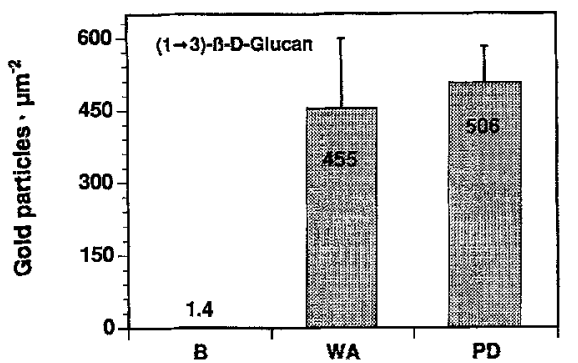

Fig. 32. Density of label over wall appositions $(W A)$ and plasmodesmata $(P D)$ after incubation with $(1 \rightarrow 3)$ - $\beta$-D-glucan antibodies. $B$, background

\section{Discussion}

The plant's extracellular matrix, the cell wall, consists of polysaccharides, glycoproteins, phenolics and several microcomponents (Carpita and Gibeaut 1993). This macromolecular complex is a dynamic structure. During wall development, modifications occur which result in specific features for the different cell types (Pennell et al. 1989;
Showalter 1993). Lectins and enzymes have been used to localize some components (Hoson 1991). Antibodies have enhanced our ability to detect such molecules because they may recognize most components of plant cell walls. Monoclonal antibodies are able to recognize precise epitopes within the different molecules of the cell wall (Knox 1992; Puhlmann et al. 1994). Such antibodies were helpful in detecting well-defined epitopes in the secretory machinery of the cells and in studying the biosynthesis of cell wall components (Northcote et al. 1989; Moore et al. 1991; Zhang and Staehelin 1992; Zhang et al. 1993).

With these tools, we have studied alterations in the composition of existing walls after fungal infection and compared these with the deposition of some major components during formation of wall appositions and the cell plate in protodermal cells of cotton root tips. We compared the labelling density over each structure in an effort to detect quantitative differences. However, certain restrictions exist with this technique. Particular carbohydrate epitopes are present on a spectrum of glycoconjugates. Such cross-reactivity exists for example with CCRC-M1 which can bind, although with quite different affinity, to both XG and PGI (Puhlmann et al. 1994). Wall 

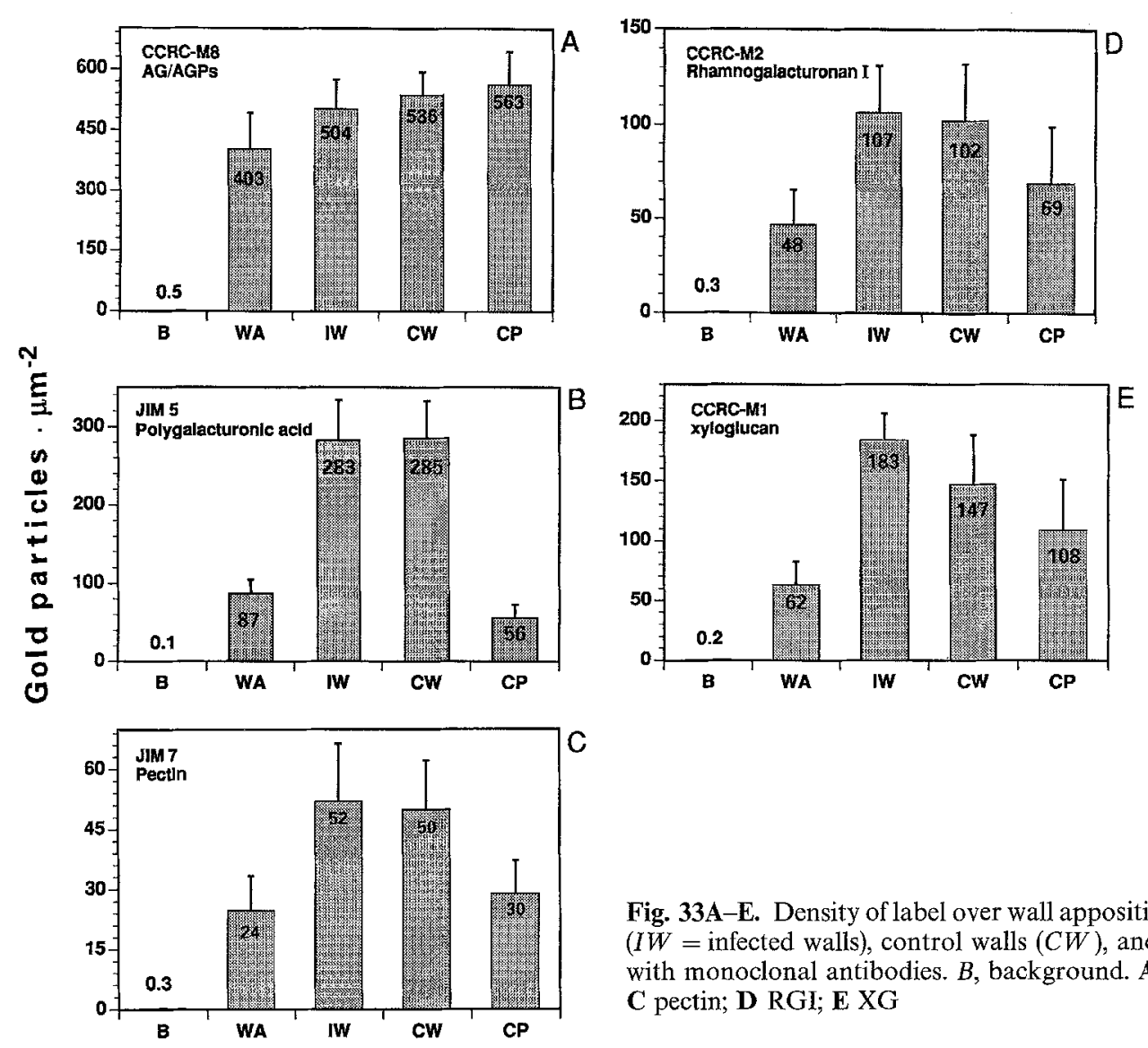

Fig. 33A-E. Density of label over wall appositions $(W A)$, walls in contact with hyphae $(I W=$ infected walls), control walls $(C W)$, and the cell plate $(C P)$ after incubation with monoclonal antibodies. B, background. A AG/AGPs; B polygalacturonic acid; C pectin; D RGI; E XG

appositions and the cell plate are in statu nascendi and epitope accessibility may change with the degree of polymerisation of the different cell wall components. Masking by the embedding medium during sample processing complicates the interpretation of quantitative differences detected by immunolabelling density measurements. However, evaluation of label density is the only means to detect differences in small areas such as the contact zone of host and parasite.

The most striking result was the high density of $(1 \rightarrow 3)$ - $\beta$-D-glucan epitopes detected in the wall apposition. Deposition of callose is a typical wound response of plants (Aist and Bushnell 1991; Smart 1991). Using antibodies, it has been detected around the penetration site of the ring nematode Cricomella xenoplax in the root cortex (Hussey et al. 1992), in contact cells surrounding vessels of tomato and cotton infected with Fusarium oxysporum (Mueller et al. 1994), and in plant leaves around the penetration site of Uromyces vicia-fabae ( $\mathrm{Xu}$ and Mendgen 1994). In addition, we observed label over plasmodesmata and spots in the cell plate but not over the Golgi apparatus. This result confirms that callose, as a reaction to wounding and infection or as a deposit along plasmodesmata (Lucas et al. 1993; Turner et al. 1994), is synthesized at the plasmalemma (Kauss 1995). In addition, we show that callose can be detected around plasmodesmata at a very early stage of cell plate development after ultra-rapid freezing and freeze substitution.
Compared to the cell plate, the wall apposition exhibited a similar density of epitopes originating from AG/AGP, XG and RGI. Provided that the high amount of callose does not influence the detection of the other cell wall components, this indicates an identical rate of synthesis in the cell plate and in the wall apposition. While pectin was detected in smaller amounts, polygalacturonic acid was present more abundantly in wall appositions. The increase of the latter component suggests a strengthening of the wall apposition since polygalacturonic acid may crosslink with $\mathrm{Ca}^{2+}$ to form junction zones (Iiyama et al. 1994).

In the already-existing cell wall, only the density of XG epitopes increased after contact with fungal hyphae. This result is in contrast to the low concentration of epitopes exposed in the wall apposition.

The synthesis of the wall components occurs at least in part in the Golgi apparatus (Moore and Staehelin 1988; Knox et al. 1990; Levy and Staehelin 1992; Driouich et al. 1994). This processing pathway did not appear to be disturbed. For example, AG/AGP was detected over trans-Golgi cisternae, trans-Golgi network, over the plasma membrane and the tonoplast. This agrees with earlier observations suggesting that AGP is secreted, moves via an endocytotic pathway into the vacuole and thus reaches the tonoplast (Herman and Lamb 1992).

This study allows a comparison of the matrix components accumulating around biotrophic microorganisms, such as Rhizobium, mycorrhiza or rust fungi and the wall 
apposition of a wilt-inducing pathogenic fungus. In the matrix (interface zone between fungal wall and host membrane) of Glomus versiforme, HRGP, cellulose and homogalacturonans were found (Bonfante-Fasolo et al. 1990, 1992; Balestrini et al. 1994). In the matrix of infection threads around rhizobia infecting the root hairs of Phaseolus vulgaris and Pisum sativum, XGs, pectin and proline-rich proteins were present (Rae et al. 1992; Sherrier and VandenBosch 1994). In the extrahaustorial matrix of the rust fungus Uromyces vignae, HRGP and AG/AGPs were detected (Stark-Urnau and Mendgen 1995). The absence of $(1 \rightarrow 3)$ - $\beta$-D-glucans (callose) seems to characterize compatible biotrophic interactions. Defense reactions, such as encapsulation of rust haustoria started with the deposition of $(1 \rightarrow 3)$ - $\beta$-D-glucans around these structures (Stark-Urnau and Mendgen 1995). Also, in mycorrhizaresistant peas, $(1 \rightarrow 3)-\beta$-glucan synthesis was induced after infection with Glomus mossae (Gollote et al. 1993).

In conclusion, we show that plant cell wall synthesis is induced around penetrating hyphae of Fusarium oxysporum. The high proportion of callose in the wall apposition characterizes the pathogenic interaction. However, we have no evidence that fungal groth is stopped by these wall appo.

We thank Dr. Holger Deising and Dr. Matthias Hahn (Lehrstuhl für Phytopathologie, Universität Konstanz, Konstanz, Germany) for reading the manuscript. We thank Dr. Michael Hahn (Complex Carbohydrate Research Center, University of Georgia, Athens, USA) for providing the antibodies CCRC-M1, CCRC-M2 and CCRC-M8 and Dr. Paul Knox (Centre for Plant Biochemistry and Biotechnology, University of Leeds, UK) for providing the antibodies JIM 5 and JIM 7. The first author is grateful to the Deutsche Akademische Austauschdienst for a scholarship.

\section{References}

Aist JR, Bushnell WR (1991) Invasion of plants by powdery mildew fungi, and cellular mechanisms of resistance. In: Cole TG, Hoch $\mathrm{HC}$ (eds) The fungal spore and disease initiation in plants and animals. Plenum Press, New York, pp 321-345

Balestrini R, Romera C, Puigdomenech P, Bonfante P (1994) Location of a cell-wall hydroxyproline-rich glycoprotein, cellulose and $\beta$-1,3-glucans in apical and differentiated regions of maize mycorrhizal roots. Planta 195: 201-209

Bohlmann H, Apel K (1991) Thionins. Annu Rev Plant Physiol Plant Mol Biol 42: 227-240

Bonfante-Fasolo P, Vian B, Perotto S, Faccio A, Knox JP (1990) Cellulose and pectin localization in roots of mycorrhizal Allium porrum: labeling continuity between host cell wall and interfacial material. Planta 180: 537-547

Bonfante-Fasolo P, Peretto R, Perotto S (1992) Cell surface interactions in endomycorrhizal symbiosis. In: Callow JA, Green JR, (eds) Perspectives in plant cell recognition. Cambridge University Press, Cambridge, pp 239-255

Brisson LF, Tenhaken R, Lamb C (1994) Function of oxidative cross-linking of cell wall structural proteins in plant disease resistance. Plant Cell 6: 1703-1712

Bushnell WR (1984) Structural and physiological alterations in susceptible host tissue. In: Bushnell WP, Roelfs AP (eds) The cereal rusts. Academic Press, Inc., Orlando, Florida, pp 477-507

Carpita NC, Gibeaut DM (1993) Structural models of primary cell walls in the flowering plants: consistency of molecular structure with the physical properties of the walls during growth. Plant $\mathbf{J} 3$ : $1-30$
Driouich A, Levy S, Staehelin A, Faye L (1994) Structural and functional organization of the Golgi apparatus in plant cells. Plant Physiol Biochem 32: 731-749

Esquerré-Tugayé MT, Lafitte C, Mazau D, Toppan AT (1979) Cell surfaces in plant-microorganism interactions. II Evidence for the accumulation of hydroxyproline-rich glycoproteins in the cell wall of diseased plants as a defense mechanism. Plant Physiol 64: 320-326

Freytag S, Arabatzis N, Hahlbrock K, Schmelzer E (1994) Reversible cytoplasmic rearrangements precede wall apposition, hypersensitive cell death and defence-related gene activation in potato/ Phytophthora infestans interactions. Planta 194: 123-135

Gibeaut DM, Carpita NC (1994) Biosynthesis of plant cell wall polysaccharides. FASEB J 8: 904-915

Gollote A, Gianinazzi-Pearson V, Giovannetti M, Sbrana C, Alvio L, Gianinazzi S (1993) Cellular localization and cytochemical probing of resistance reactions to arbuscular mycorrhizal fungi in a 'locus a' $\mathrm{myc}^{-}$mutant of Pisum satioum L. Planta 191: $122-122$

Hächler H, Hohl HR (1984) Temporal and spatial distribution patterns of collar and papillae wall appositions in resistant and susceptible tuber tissue of Solanum tuberosum infected by Phytophthora infestans. Physiol Plant Pathol 24: 107-118

Hayat MA (1975) Positive staining for electron microscopy. Van Nostrand Rheinhold Company, New York

Heath MC (1972) Ultrastructure of host and nonhost reactions to cowpea rust. Phytopathology 62: 27-38

Herman EM, Lamb CJ (1992) Arabinogalactan-rich glycoproteins are localized on the cell surface and in intravacuolar multivesicular bodies. Plant Physiol 98: 264-272

Hohl HR, Suter E (1976) Host parasite interfaces in a resistant and susceptible cultivar of Solanum tuberosum inoculated with Phytophthora infestans: leaf tissue. Can J Bot 54: 1956-1970

Homblé F, Foissner I (1993) Electron microscopy and electrophysiology of local cell wall formation in Chara corallina. Plant Cell Physiol 34: 1283-1289

Hoson T (1991) Structure and function of plant cell walls: immunological approaches. Int Rev Cytol 130: 233-268

Hussey RS, Mims CW, Wescott SW (1992) Immunocytochemical localization of callose in root cortical cells parasitized by the ring nematode Criconemella xenoplax. Protoplasma 171: 1-6

Iiyama K, Lam TB, Stone BA (1994) Covalent cross-links in the cell wall. Plant Physiol 104: 315-320

Kauss H (1995) Callose synthesis. In: Smallwood M, Knox P, Bowles DJ (eds) Membranes: Specialized functions in plant cells. JAI Press, In press

Knox JP (1992) Molecular probes for the plant cell surface. Protoplasma 167: $1-9$

Knox JP, Day S, Roberts K (1989) A set of cell surface glycoproteins forms an early marker of cell position, but not cell type, in the root apical meristem of Daucus carota. Development 106: 47-56

Knox JP, Linstead PJ, King J, Cooper C, Roberts K (1990) Pectin esterification is spatially regulated both within cell walls and between developing tissues of root apices. Planta 181: 512-521

Kunoh H (1982) Primary germ tubes of Erysiphe graminis conidia. In: Asada Y (ed) Plant infection: the physiological and biochemical basis. Japan Sci Soc Press, Tokyo/Berlin, pp 45-59

Levy S, Staehelin A (1992) Synthesis, assembly and function of plant cell wall macromolecules. Curr Opin Cell Biol 1992: $856-862$

Lucas WJ, Ding B, Van der Schoot C (1993) Plasmodesmata and the supracellular nature of plants. New Phytol 125: 435-476

Mendgen K, Welter K, Scheffold F, Knauf-Beiter G (1991) High pressure freezing of rust infected plant leaves. In: Mendgen $\mathrm{K}$, Leseman DE (eds) Electron microscopy of plant pathogens. Springer Verlag, Berlin Heidelberg, pp 31-41

Moore PJ, Staehelin LA (1988) Immunogold localization of the cell-wall-matrix polysaccharides rhamnogalacturonan $I$ and xyloglucan during cell expansion and cytokinesis in Trifolium pratense L.; implication for secretory pathways. Planta 174: 433-445 
Moore PJ, Swords KMM, Lynch MA, Staehelin LA (1991) Spatial organization of the assembly pathways of glycoproteins and complex polysaccharides in the Golgi apparatus of plants. J Cell Biol 112: 589-602

Mueller WC, Morgham AT, Roberts EM (1994) Immunocytochemical localization of callose in the vascular tissue of tomato and cotton plants infected with Fusarium oxysporum. Can J Bot 72 : 505-509

Northcote DH, Davey R, Lay J (1989) Use of antisera to localize callose, xylan and arabinogalactan in the cell-plate, primary and secondary walls of plant cells. Planta 178: 353-366

Pennell RI (1992) Cell surface arabinogalactan proteins, arabinogalactans and plant development. In: Callow JA, Green JR (eds) Perspectives in plant recognition. Cambridge University Press, Cambridge, pp 105-121

Pennell RI, Knox JP, Scofield GN, Selvendran RR, Roberts K (1989) A family of abundant plasma membrane-associated glycoproteins related to the arabinogalactan proteins is unique to flowering plants. J Cell Biol 108: 1967-1977

Puhlmann J, Bucheli E, Swain MJ, Dunning N, Albersheim P, Darvill AG, Hahn MG (1994) Generation of monoclonal antibodies against plant cell-wall polysaacharides. Plant Physiol 104: 699-710

Rae A, Bonfante-Fasolo P, Brewin N (1992) Structure and growth of infection threads in the legume symbiosis with Rhizobium leguminosarum. Plant J 2(3): 385-395

Ride JP, Pearce RB (1979) Lignification and papilla formation at sites of attempted penetration of wheat leaves by non-pathogenic fungi. Physiol Plant Path 15: 7992

Roberts K (1994) The plant extracellular matrix: in a new expansive mood. Curr Op Cell Biol 6: 688-694

Rodriguez-Gálvez E, Mendgen K (1995) The Infection process of Fusarium oxysporum in cotton root tips. Protoplasma, In press

Russo VM, Bushnell WR (1989) Responses of barley cells to puncture by microneedles and to attempted penetration by Erysiphe graminis f. sp. hordei system. Can J Bot 67: 2912-2921
Sargent C, Gay JL (1977) Barley epidermal apoplast structure and modification by powdery mildew contact. Physiol Plant Pathol 11: 195-205

Sherrier DJ, VandenBosch KA (1994) Localization of repetitive proline-rich proteins in the extracellular matrix of pea root nodules. Protoplasma 183: 148-161

Sherwood RT, Vance CP (1982) Initial events in the epidermal layer during penetration. In: Asada Y (ed) Plant infection: The physiological and biochemical basis. Japan Sci Soc Press/Springer Verlag, Tokyo/Berlin, pp 27-44

Showalter AM (1993) Structure and function of plant cell wall proteins. Plant Cell 5: 9-25

Smart MG (1991) The plant cell wall as a barrier to fungal invasion. In: Cole GT, Hoch HC (eds) The fungal spore and disease initiation in plants and animals. Plenum Press, New York and London, pp 47-66

Stark-Urnau M, Mendgen K (1995) Sequential deposition of plant gycoproteins and polysaccharides into the host-parasite interface of Uromyces vignae and Vigna sinencis. Evidence for endocytosis and secretion. Protoplasma 186: 1-11

Steffan W, Kovác P, Albersheim P, Darvill AG, Hahn MG (1995) Characterization of a monoclonal antibody that recognizes an arabinosylated (1-6)- $\beta$-D-galactan epitope in plant complex carbohydrates. Carbohydr Res, In press

Turner A, Wells B, Roberts K (1994) Plasmodesmata of maize root tips: structure and composition. J Cell Sci 107: 3351-3361

Xu H, Mendgen K (1994) Endocytosis of 1,3- $\beta$-glucans by broad bean cells at the penetration site of the cowpea rust fungus (haploid stage). Planta 195: 282-290

Zhang GF, Driouich A, Staehelin A (1993) Effect of monensin on plant Golgi: re-examination of the changes in cisternal architecture and function activities of the Golgi apparatus of sycamore suspension-cultured cells. J Cell Sci 104: 819-831

Zhang GF, Staehelin LA (1992) Functional compartmentation of the Golgi apparatus of plant cells. Plant Physiol 99: 1070-1083 